\title{
The Changing Legislation AND REgulation OF CARBON CAPTURE AND STORAGE: Impacts on Purpose, Policy, AND PRoJects
}

\author{
Michael G Massicotte, Alan L Ross, \\ AND CHIDINMA B THOMPSON*
}

The Government of Alberta is implementing carbon capture and storage (CCS) technology in order to reduce carbon dioxide emissions. With the enactment of the Carbon Capture and Storage Statutes Amendment Act, 2010 in November 2010, Alberta became the first jurisdiction in Canada to have comprehensive CCS legislation. This article describes CCS technology, considers the impact of the new legislation and potential interjurisdictional conflicts, and briefly compares the CCS legislation of other jurisdictions with Alberta's legislation.
Le gouvernement de l'Alberta met en place une technologie de captage et de stockage du dioxyde de carbone (CSC) dans le but de réduire les émissions de dioxyde de carbone. Avec l'adoption de la loi amendée Carbon Capture and Storage StatutesAmendmentAct, 2010 en novembre 2010, l'Alberta est devenue la première juridiction au Canada à avoir une loi générale en matière de CSC. Cet article décrit la technologie pertinente et examine les effets de la nouvelle loi et les conflits potentiels entre ressorts. L'article compare aussi rapidement la loi en la matière d'autres juridictions avec celle de l'Alberta.

\section{TABLE OF CONTENTS}

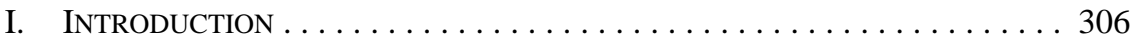

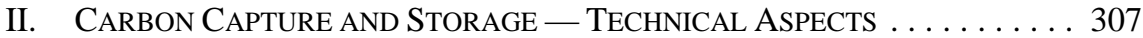

III. Legislative, POLICY, AND REgUlatory History

PRedating THe CCS Statutes AmENDMENT ACT . . . . . . . . . . . 309

A. The Climate Change Framework . . . . . . . . . . . . . 309

B. PRe-CCS Statutes AmENDMENT ACT POLICy History

- Project Financing ANd DeVELOPMENT ............. 311

C. Pre-CCS Statutes Amendment Act Regulatory History . . . . 314

IV. THE CCS StatUTES AMENDMENT ACT AND THE

CS TENURE REgULATION ....................... 315

A. OWNERSHIP OF STORAGE DOMAIN AND DisPosition REgIME $\ldots 316$

B. LONG-TERM LiABILITY REgIME $\ldots \ldots \ldots \ldots \ldots \ldots \ldots \ldots \ldots \ldots \ldots$

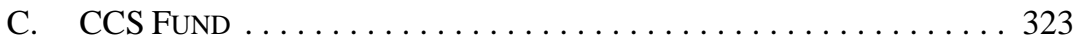

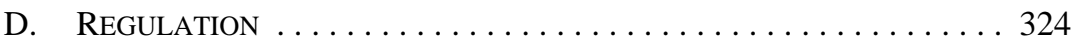

V. Post-CCS Statutes AMENDMENT ACt REgUlatory FrameWORK . . . . 325

A. ERCB ENERgy DEVELOPMENT APPLICATION (Directive 056)

AND $\mathrm{CO}_{2}$ Disposal SCHEME APPLICATION (DiRECTIVE 065) $\ldots 326$

B. Monitoring, RePorting, AND SAFETy . .............. 326

C. ClOSURE - SusPension, ABANDONMENT,

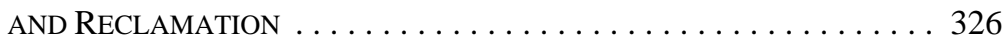

D. REgUlatory GaPS . . . . . . . . . . . . . . . . . . . . . . . . . . 327

VI. Potential INTERJURISDICTIONAL CONFLICT $\ldots \ldots \ldots \ldots \ldots \ldots \ldots 328$

VII. COMPARISON OF ALBERTA'S LEgISLATIVE CHANGES

WITH OTHER CCS JURISDICTIONS $\ldots \ldots \ldots \ldots \ldots \ldots \ldots \ldots \ldots$

Michael G Massicotte and Alan L Ross are Partners and Chidinma B Thompson is an Associate at the Calgary office of Borden Ladner Gervais LLP. 
A. OWNERShip of StORAGE Domain $\ldots \ldots \ldots \ldots 31$

B. LONG-TERM LIABILITY . . . . . . . . . . . . . . . . . . . . . 332

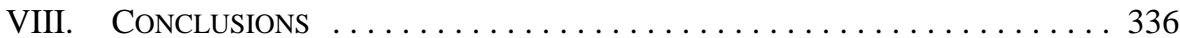

\section{INTRODUCTION}

In 2008 the Government of Alberta committed \$2 billion to large-scale carbon capture and storage (CCS) projects. CCS is a process that captures carbon dioxide $\left(\mathrm{CO}_{2}\right)$ emissions from large industrial emitters and stores them in geological formations kilometres below the earth's surface. To assist in facilitating the implementation of this technology, on 1 November 2010, Bill 24, Carbon Capture and Storage Statutes Amendment Act, $2010^{1}$ was introduced in the Alberta Legislature. On 2 December 2010, it received Royal Assent, making Alberta the first jurisdiction in Canada to enact comprehensive CCS legislation. ${ }^{2}$ On 28 April 2011, the Government of Alberta issued the Carbon Sequestration Tenure Regulation. $^{3}$

The CCS Statutes Amendment Act contains significant amendments to the Mines and Minerals Act, ${ }^{4}$ the Oil and Gas Conservation Act, ${ }^{5}$ the Energy Resources Conservation Act, ${ }^{6}$ the Public Lands Act, ${ }^{7}$ and the Surface Rights Act. ${ }^{8}$ These amendments include:

- $\quad$ Clarification of pore space ownership in Alberta. The pore space below the surface of all land in Alberta, other than land owned by the federal Crown, has been declared to be the property of the Crown in right of Alberta.

- The creation of a disposition scheme for pore space for the purposes of sequestration.

- $\quad$ Acceptance by the province of long-term liability for injected carbon dioxide. A CCS operator will be responsible for the CCS operation until it substantiates that the stored carbon dioxide is "contained” and a closure certificate has been issued. Thereafter, the Alberta government will be the owner of the sequestered $\mathrm{CO}_{2}$ and, on an indefinite basis, will assume the monitoring and other post-closure responsibilities. The Alberta government is obligated to indemnify the operator with respect to any third party liability related to the injected carbon dioxide.

- $\quad$ The creation of a stewardship fund, financed by CCS operators, to be used for remedial and ongoing monitoring costs for CCS projects. CCS operators will pay into the Post-closure Stewardship Fund (in an amount yet to be specified by

Third Sess, 27th Leg, Alberta, 2010, SA 2010, c 14 [CCS Statutes Amendment Act].

Albeit by way of amendments to existing legislation.

AR 68/2011[CS Tenure Regulation]. See Government of Alberta, Information Bulletin, "New regulation helps enable carbon storage" (28 April 2011), online, Government of Alberta <http://alberta.ca/ home/NewsFrame.cfm?ReleaseID=/acn/201104/302889DAAB79F-0A5B-1418-BA33BB135909 F2D8.html> [“New regulation”].

RSA 2000, с M-17 [MMA].

RSA 2000, c O-6 [OGCA].

RSA 2000, c E-10 [ERCA].

RSA 2000, c P-40 [PLA].

RSA 2000, c S-24 [SRA]. 
regulation). The fund will be managed by the Alberta government and will be used for ongoing monitoring costs and any remedial work required following the issuance of a closure certificate. Any costs incurred by the Crown as a result of the release of obligations by the lessee to indemnify the Crown under section 56(2)(a) of the $M M A$, and any third party liability indemnity claims, are not covered by the Post-closure Stewardship Fund.

The CS Tenure Regulation establishes the procedural requirements for CCS operators seeking tenure rights for potential deep carbon storage sites. These include: a legal definition of pore space for sequestration purposes, a five-year evaluation permit for determining storage site suitability and a 15-year sequestration lease intended for longer term commercial needs, one dollar per hectare annual rental rates and permit and lease application fees of \$625; “the maximum area for permits and leases of 73,728 hectares (eight townships)"; "the minimum carbon dioxide injection depth of one kilometre" (1,000 metres) below the earth's surface, and monitoring, measurement and verification plans and closure plans (which require the Minister's approval and updates every three years). ${ }^{9}$

This article consists of seven parts. Part I provides an introduction. Part II discusses some of the technical aspects of CCS and its relevance to industry and government. Part III traces the pre-CCS Statutes Amendment Act legislative, policy, and regulatory history. Part IV addresses the highlights of the CCS Statutes Amendment Act and CS Tenure Regulation. Part $\mathrm{V}$ considers the post-CCS Statutes Amendment Act regulatory framework for CCS projects in Alberta. Part VI identifies potential issues of interjurisdictional conflicts, and Part VII briefly compares select aspects of Alberta's CCS legislation with those of other jurisdictions.

\section{Carbon Capture And Storage - Technical Aspects}

CCS refers to a collection of emerging, innovative technologies aimed at reducing $\mathrm{CO}_{2}$ emissions into the atmosphere. CCS captures and permanently stores high volumes of $\mathrm{CO}_{2}$ emissions in deep underground geological formations, either onshore or offshore. This article focuses on onshore storage only.

There are various stages in the CCS process: (1) capture, separation, and compression; (2) transportation; (3) underground injection; (4) closure; and (5) post-closure. It is anticipated that the capture of $\mathrm{CO}_{2}$ will predominately occur at the sites of large final emitters, including oil refineries, fossil fuel generation units, and oil sands production and upgrading sites. The capture of the $\mathrm{CO}_{2}$ is the most expensive of the stages - it accounts for approximately 75 percent of the overall CCS project cost. ${ }^{10}$

\footnotetext{
"New regulation," supra note 3.

The capture cost was estimated in 2009 to range from \$70 to more than \$150 per tonne - see Alberta Carbon Capture and Storage Development Council, Accelerating Carbon Capture and Storage Implementation in Alberta: Final Report, (4 March 2009) at 10, online, Alberta Energy <http://www. energy. alberta.ca/Org/pdfs/CCS_Implementation.pdf> [ACCSDC Final Report].
} 
Once captured, the $\mathrm{CO}_{2}$ must be compressed to form a supercritical fluid (that is, possessing properties of both a gas and a liquid $)^{11}$ and then transported by pipeline, truck, or other mode of transportation, to an injection well. ${ }^{12}$ The main advantage of storing $\mathrm{CO}_{2}$ in a supercritical state is that the required storage volume is significantly less than if $\mathrm{CO}_{2}$ was at standard room pressure conditions. ${ }^{13}$ "In order to maintain the supercritical state of $\mathrm{CO}_{2}$, it must be injected at least 800 metres below the surface” of the earth. ${ }^{14}$ In addition to ongoing monitoring and verification, long-term monitoring of the storage site must be undertaken at the post-closure stage, following the cessation of $\mathrm{CO}_{2}$ injection.

The four main onshore geologic storage domains for CCS are: (1) depleted oil and gas reservoirs; ${ }^{15}$ (2) deep saline formations $;{ }^{16}$ (3) unminable coal beds $;{ }^{17}$ and (4) salt caverns. ${ }^{18}$ Carbon dioxide storage sites require the presence of both a reservoir with sufficient injectivity and a seal to prevent migration. ${ }^{19}$

In Alberta, porous sedimentary rock formations beneath solid caprock are ideally suited for the injection and safe and secure underground storage of $\mathrm{CO}_{2}$. Liquid $\mathrm{CO}_{2}$ fills the small spaces in the porous rock, while the solid caprock above ensures that the liquid stays in place. ${ }^{20}$ Depleted oil and gas reservoirs are also, in most cases, the most economically

11 Supercritical means that the $\mathrm{CO}_{2}$ "is dense like a liquid but has viscosity like a gas.” US Department of Energy, 2010 Carbon Sequestration Atlas of the United States and Canada (November 2010) at 26 [DOE 2010 Atlas].

12 Nigel Bankes \& Jenette Poschwatta, "Carbon Capture and Storage in Alberta: Learning From the Acid Gas Disposal Analogy” (2007) 97 Canadian Institute of Resources Law 1 at 1.

13 DOE 2010 Atlas, supra note 11 at 26.

14 Peter S Glaser et al, "Global Warming Solutions: Regulatory Challenges and Common Law Liabilities Associated with the Geologic Sequestration of Carbon Dioxide,” (2008) 6:2 Georgetown Journal of Law \& Public Policy 429 at 430 .

$15 \quad$ As stated in DOE 2010 Atlas, supra note 11 at 28:

Mature oil and gas reservoirs ... consist of a layer of permeable rock ... with a layer of nonpermeable rock ... such that the caprock forms a seal that holds the hydrocarbons in place. The characteristics that have held the oil and gas in the reservoirs for millions of years make them excellent target locations for the geologic storage of $\mathrm{CO}_{2}$. An added benefit of oil and gas reservoirs is that they have been extensively explored, which generally results in a wealth of data available to plan and manage proposed CCS efforts.

As a value-added benefit, $\mathrm{CO}_{2}$ injected into a mature oil reservoir can enable ... recovery of an additional 10-15 percent of [a reservoir's original oil in place].

However, there has been commentary on the increased risk of leakage pathways in depleted oil and gas formations due to natural faults in, and multiple penetrations into, the caprock. See Glaser et al, supra note 14 at 433; Nigel Bankes, Jenette Poschwatta \& E Mitchell Shier, "The Legal Framwork for Carbon Capture and Storage in Alberta” (2008) 45:3 Alta L Rev 585 at 596-97.

$16 \quad$ As stated in the DOE 2010 Atlas, ibid at 27: "Saline formations are layers of porous rock that are saturated with brine. They are much more extensive than coal areas or oil- and gas-bearing rock and represent an enormous potential for $\mathrm{CO}_{2}$ geologic storage. However, less is known about saline formations ... [and therefore there is] uncertainty regarding the suitability of saline formations for $\mathrm{CO}_{2}$ storage."

$17 \quad$ As stated in the DOE 2010 Atlas, ibid at 29: "Coal seams that are too deep or too thin to be economically mined are viable for $\mathrm{CO}_{2}$ storage."

18 Salt caverns have been used as natural gas storage sites for many years. However, storage in salt caverns is often costly, since the cavern must be created by pumping water into a salt formation to dissolve the salt, creating an empty storage space. Bankes, Poschwatta \& Shier, supra note 15 at 592; Stefan Bachu \& Leo Rothenburg, "Carbon Dioxide Sequestration in Salt Caverns: Capacity and Long Term Fate" (Paper delivered at the Second Annual Conference on Carbon Sequestration: Developing \& Validating the Technology Base to Reduce Carbon Intensity, 5-8 May 2003) at 1, online: National Energy Technology Laboratory <http://www.netl.doe.gov/publications/proceedings/03/carbon-seq/PDFs/011. pdf>.

19 DOE 2010 Atlas, supra note 11 at 28. Porous or fractured sedimentary rock may be saturated with brine, oil, or gas. If permeable (e.g. sandstones), the location may be well-suited for $\mathrm{CO}_{2}$ storage, so long as there is an impermeable seal (e.g. shales) (ibid at 26).

20 Government of Alberta, Facts About Carbon Capture and Storage (March 2011), online: Alberta Department of Energy (ADOE) <http://www.energy.alberta.ca/CCS/pdfs/FactSheetDetailedCCS.pdf> . 
efficient storage sites since their geologic characteristics are well-known and most are already easily accessible by way of existing pipelines. As has been stated elsewhere: "The same geological endowment that makes Alberta an energy powerhouse means that it is also ideally situated for the implementation of large-scale CCS due to the close proximity of concentrated carbon dioxide $\left(\mathrm{CO}_{2}\right)$ sources and underground geological formations in the Western Canadian Sedimentary Basin suitable for deep storage.”21

CCS technology is still in its infancy. The Weyburn-Midale CCS project is Canada's first large-scale carbon capture project. It has been storing $\mathrm{CO}_{2}$ that has been produced by the Dakota Gasification Company's Great Plains Synfuels Plant in Beulah, North Dakota, for over 30 years in connection with its production of methane from coal. ${ }^{22}$ Since $2000, \mathrm{CO}_{2}$ has been captured and transported to Weyburn, Saskatchewan, via a 320 kilometre pipeline. ${ }^{23}$ It has been injected in Weyburn and used for the purpose of enhancing oil production from the depleted oil reservoirs, first discovered in 1954. At Weyburn, “over 16 megatonnes of $\mathrm{CO}_{2}$ has been injected since the start of the project." ${ }^{24}$ It remains one of the world's first and largest CCS demonstration projects ${ }^{25}$ and stores approximately 1.8 million tonnes of $\mathrm{CO}_{2}$ every year. $^{26}$

\section{Legislative, Policy, AND Regulatory History Predating the CCS Statutes Amendment ACt}

The relevance and content of the CCS Statutes Amendment Act is better understood in light of the legislative, policy, and regulatory history for CCS, particularly with respect to the framework for emissions reduction set out by the federal and provincial governments.

\section{A. The Climate Change Framework}

As set out in the Copenhagen Accord ${ }^{27}$ and reinforced in the Cancun Agreements, ${ }^{28}$ Canada has committed to reducing its greenhouse gas (GHG) emissions to 17 percent below

Teresa Meadows \& Tony Crossman, “A Tale of Two Provinces: Imposing Greenhouse Gas Emissions Constraints Through Law and Policy in Alberta and British Columbia” (2010) 47:2 Alta L Rev 421 at 434.

22 Dakota Gasification Company, Great Plains Synfuels Plant, online: Dakota Gasification Company $<$ http://www.dakotagas.com>.

23 ACCSDC Final Report, supra note 10 at 59.

24 Government of Canada, Canada's Action on Climate Change, Carbon Capture and Storage (9 June 2010), online: Government of Canada <http://climatechange.gc.ca/default.asp?lang=En\&n=D22 D143 E-1> [Canada's Action on Climate Change].

Ibid.

DOE 2010 Atlas, supra note 11 at 12 .

(18 December 2009) in United Nations Framework Convention on Climate Change (UNFCCC), Report of the Conference of the Parties on its fifteenth session held in Copenhagen from 7 to 19 December 2009 (30 March 2010) 4 at 6, online: UNFCCC <http://unfccc.int/resource/docs/2009/cop15/eng/11a01.pdf>. UNFCCC, Report of the Conference of the Parties serving as the meeting of the Parties to the Kyoto Protocol on its sixth session, held in Cancun From 29 November to 10 December 2010: Part Two: Action taken by the conference of the Parties serving as the meeting of the Parties to the Kyoto Protocol at its sixth session (15 March 2011), online: UNFCCC <http://unfccc.int/resource/docs/2010/cmp6/ eng/12a01.pdf>; UNFCCC, Report of the Conference of the Parties on its sixteenth session, held in Cancun from 29 November to 10 December 2010: Part Two: Action taken by the conference of the Parties at its sixteenth session (15 March 2010), online: UNFCCC <http://unfccc.int/resource/docs/ 2010/cop16/eng/07a01.pdf>. 
its 2005 levels by 2020, which aligns with the target set by the United States. ${ }^{29}$ Canada's commitments to reduce emissions are a key driver of CCS legislation and form part of an extensive policy history.

From 2004 to 2007, facilities in Alberta emitting in excess of 100,000 tonnes of GHG per year were required to file an annual emissions report under the Specified Gas Reporting Regulation. ${ }^{30}$ Those reports provided the data that was used to arrive at the baseline for emissions reduction targets introduced in 2007, under amendments to the Climate Change and Emissions Management $\mathrm{Act}^{31}$ and the Specified Gas Emitters Regulation. ${ }^{32}$ Since 1 July 2007, established facilities with annual emissions in excess of 100,000 tonnes have been required annually to reduce their emissions intensity ${ }^{33}$ by 12 percent below their 2003-2005 baseline emissions intensity. ${ }^{34}$ There is a $\$ 200$ per tonne fine when an emitter fails to meet its annual targets. ${ }^{35}$ In order to avoid the fine, the emitter has three compliance options: (1) meet the target reductions; (2) contribute \$15 per tonne to the Climate Change and Emission Reduction Fund; or (3) purchase emissions offsets produced by project developers or aggregators under the Alberta Offset System. ${ }^{36}$

In Alberta's 2008 Climate Change Strategy, implementing CCS was identified as an action item required to reduce the overall rise in the atmospheric concentrations of $\mathrm{CO}_{2}{ }^{37}$ The stated goal was “to store quantities of $\mathrm{CO}_{2}$ in Alberta's geological formations instead of releasing them into the atmosphere." 38 The province's emphasis on CCS as the primary mechanism to reduce GHG emissions was made very clear:

Alberta has a unique opportunity to implement carbon capture and storage to substantially reduce our greenhouse gas emissions. $\mathrm{CO}_{2}$ emissions can be captured where they are produced, transported and stored in geological formations (such as depleted oil and gas reservoirs, coalbeds, and deep saline aquifers) which may be located hundreds of kilometres away. Over the past five years, there has been a growing interest by

Government of Canada, Canada’s Action on Climate Change, Canada at Copenhagen (10 August 2010), online: Government of Canada <http://climatechange.gc.ca/cdp15-cop15/default.asp?lang= En\&n= 97EB07-1>. (1)

SA 2003, c C-16.7, as amended by Climate Change and Emissions Management Amendment Act, 2007 SA 2007, c 4.

$32 \quad$ Alta Reg $139 / 2007$

$33 \quad$ Ibid , s 3(2). The targets are "intensity" based. There is no aggregate or total cap on emissions. Although section 3 of the Climate Change and Emissions Management Act, supra note 31, requires emissions intensity to be reduced by 50 percent over 1990 levels by 2020, depending on the growth of Alberta's gross domestic product, total emissions may climb while emissions intensity may drop 50 percent or more.

There is a legislated phase-in of the emissions intensity reduction for new facilities. New facilities, or facilities that began operation on or after 1 January 2000 and have completed less than eight years of commercial operation, have been given a gradated reduction obligation, increasing 2 percent per year starting in the fourth year of commercial operation up to a reduction obligation of 12 percent. See Specified Gas Emitters Regulation, supra note 32, s 3(3); Alberta Environment, Technical Guidance for Completing Specified Gas Baseline Emission Intensity Applications: Specified Gas Emitters Regulation (May 2010) at 8-9, online: Alberta Environment <http://environment.alberta.ca/documents/ TechnicalGuidance-for-Completing-Specified-Gas-Baseline-Emission-Intensity-Applications.pdf> [Technical Guidance].

Specified Gas Emitters Regulation, supra note 32, s 28(1).

Technical Guidance, supra note 34 at 11.

Other action items identified included conserving and using energy efficiently and greening energy production. Alberta Environment, Alberta's 2008 Climate Change Strategy: Responsibility/Leadership/ Action (January 2008) at 7, online: Alberta Environment <http://environment.gov.ab.ca/info/library/ 7894.pdf $>$.

Ibid at 17. 
industry in using $\mathrm{CO}_{2}$ for enhanced oil recovery as a way of extracting more oil and making productive use of $\mathrm{CO}_{2}$. There is a significant opportunity for Alberta to build on these prospective commercial projects and begin injecting much larger volumes into other types of geological formations. Ultimately, $\mathrm{CO}_{2}$ capture and storage technologies provide the province with the greatest potential to substantially reduce greenhouse gas emissions while, at the same time, retaining our ability to produce and provide energy to the rest of the world. ${ }^{39}$

Turning to the federal government's climate change initiatives, early federal regulation was directed at both the oil and gas and electricity sectors. Under the 2008 federal climate change regulatory framework for industrial GHG emissions, reduction targets based on CCS are to be developed, effective 2018, for upgrader and in situ facilities in the oil sands sector, and for new coal-fired electricity-generating facilities that begin operation in 2012 or later. ${ }^{40}$ On 23 June 2010, the federal government announced its plans to phase out coal-fired electricity generation. ${ }^{41}$ To this end, regulations have been proposed, effective 1 July 2015, which provide for stringent performance standards to be applied to new coal-fired electricity generation units and those coal-fired units that have reached the end of their economic life. ${ }^{42}$

\section{B. Pre-CCS Statutes Amendment Act Policy History - Project Financing AND DeVelopment}

A second foundation for the CCS Statutes Amendment Act is found in a series of federal and provincial policy initiatives spanning from 2007 to 2010, which address the financing and development of CCS projects. First, in March 2007, the federal and Alberta governments established the joint federal-provincial ecoEnergy Carbon Capture and Storage Task Force (the Task Force), "to provide advice on how government and industry can work together to facilitate and support the development of [CCS] opportunites in Canada." ${ }^{43}$ In its final report, the Task Force Report, the Task Force recommended three immediate actions "to get Canada on the pathway to successful CCS implementation," as well as three subsequent actions, which the Task Force stated "should be undertaken as next steps." 44 The Task Force recommended the following three immediate action items:

(1) "Federal and Provincial governments should allocate $\$ 2$ billion in new public funding to leverage the billions of dollars of industry investment [required for] the first CCS projects”;

40

Environment Canada, Turning the Corner: Regulatory Framework for Industrial Greenhouse Gas Emissions (March 2008) at iii, online: Environment Canada <http://www.ec.gc.ca/doc/viragecorner/2008-03/pdf/COM-541_Framework.pdf >.

$41 \quad$ Environment Canada, News Release, "Government of Canada to Regulate Emissions from Electricity Sector" (23 June 2010), online: Environment Canada <http://www.ec.gc.ca/default.asp?lang=En\&n= 714D9AAE-1\&news=E5B59675-BE60-4759-8FC3-D3513EAA841C $>$.

42 Ibid. Reduction of Carbon Dioxide Emissions from Coal-Fired Generation of Electricity Regulations, Regulatory Impact of Analysis Statement, (2011) C Gaz II, 2779 at 2780.

43 Natural Resources Canada, The ecoEnergy Carbon Capture and Storage Task Force, Canada's Fossil Energy Future: The Way Forward on Carbon Capture and Storage (9 January 2008) at i, online: Natural Resources Canada <http://www.nrcan.gc.ca/com/resoress/publications/fosfos/fosfos-eng.php> [Task Force Report]. 
(2) The first CCS projects should be moved forward by: (a) providing regulatory clarity through confirmation of legislation and regulation related to pore-space ownership and disposition rights; (b) "clearly articulating the terms for the transfer of longterm liability from industry to government"; and (c) "increasing the transparency of regulatory processes"; ${ }^{45}$ and

(3) "Federal and Provincial governments should ensure as much opportunity for CCS projects under the GHG regulatory frameworks as for any other qualifying emission reduction option. This will require the creation of CCS-specific measurement and crediting protocols." 46

These three immediate action items were said to "require urgent attention as they are intended to address the two main barriers facing CCS today: the financial gap associated with CCS projects today, and current gaps in regulatory frameworks." 47 They were identified by the Task Force as having to be "overcome ... in short order, to succeed with CCS."

The Task Force also identified the following three subsequent action items:

(1) "Industry and both government levels should form a collaborative framework, including an advisory group over the next two years to coordinate discussion, to institutionalize learning, and to potentially carry out specific aspects of [the three immediate action items]";

(2) “Federal and Provincial governments should provide stable financial incentives to help drive CCS activities beyond the phase-one projects ... [which] may include the continuation of RFPs ... CO $\mathrm{CO}_{2}$ storage incentives, and/or the use of tax and royalty incentives"; and

(3) "Canadian-based research organizations and technology developers should focus research and demonstration efforts on CCS to achieve two goals: to drive down the cost of existing CCS technologies; and to enable the deployment of next generation CCS technology and processes. The Federal and Provincial governments should provide financial support for these activities."

Subsequently, policy developments turned to address CCS financing. The Government of Alberta established the Alberta Carbon Capture and Storage Development Council in April $2008,{ }^{50}$ and in July 2008, the Alberta government announced that it would invest $\$ 2$ billion

Ibid at ix, 23. The Task Force recommended that "[c]onfirming provincial jurisdiction over the ownership and disposition of pore space, and clearly articulating that industry will not face long-term liability obligations associated with CCS will help create a regulatory environment that is conducive for CCS" (ibid at ix).

$46 \quad$ Ibid at ix, 23. According to the Task Force, "[e]nsuring a role for CCS in meeting emission reductions obligations," and ensuring that any $\mathrm{CO}_{2}$ credits from CCS are "no less tradable or valuable" than other credits, will help create some potential commercial value for CCS activities (ibid at 30). Ibid at ix.

Ibid.

Ibid at 23.

Government of Alberta, Alberta Carbon Capture and Storage Council (4 August 2011), online: ADOE $<$ http://www.energy.alberta.ca/Initiatives/1690.aspx>. 
to fund CCS projects. ${ }^{51}$ In 2009 the Alberta government enacted the Carbon Capture and Storage Funding Act, ${ }^{52}$ which was proclaimed in force on 4 June 2009. Section 1 of the CCSFA sets forth its purposes as being "to encourage and expedite the design, construction and operation of [CCS] projects in Alberta.” Section 3 of the CCSFA provides the Minister of Energy with the authority to "make grants to carry out the purpose" of the CCSFA, in an aggregate amount not to exceed $\$ 2$ billion.

Again, the Province of Alberta very clearly articulated that among renewable energy, conservation, and CCS, the province's focus in reducing GHG emissions would be on CCS. As stated by the Alberta Carbon Capture Storage Development Council:

CCS is recognized globally as a technology possessing the potential to dramatically reduce GHG emissions. There is agreement among key stakeholders in Alberta that CCS holds the promise to significantly contribute to Alberta's long-term climate change strategy provided the economic and policy hurdles confronting CCS can be overcome. While contributions from renewable energy development and conservation are an important part of Alberta's carbon intensity reduction plan, some 70 per cent of Alberta's potential reductions are foreseen to arise from CCS. ${ }^{53}$

The reduction of GHG emissions as a policy driver was reiterated in the December 2008 Alberta government publication entitled Launching Alberta's Energy Future: Provincial Energy Strategy. ${ }^{54}$ In that publication, then Minister of Energy Mel Knight described the Provincial Energy Strategy as “a comprehensive plan for Alberta's energy future [that] supports our government's priority of ensuring that our energy resources are developed in an environmentally sustainable way." 55 The Minister broadly summarized three strategic outcomes set out in the report, which he stated are immediately required to realize Alberta's vision for its energy future: (1) clean energy production; (2) wise energy use; and (3) sustained economic prosperity. ${ }^{56}$ The Minister stated that the first outcome, clean energy production, "will be achieved through the application of energy technology leadership," including the government's investment in the development and implementation of gasification technology and CCS. ${ }^{57}$ He went on to state that "[i]n a world counting on energy from all sources, Alberta's advantage lies in being able to produce and consume fossil fuels in a far cleaner way, but [the government's] commitment extends to the increasing role of alternative and renewable energy." ${ }^{\text {"58 }}$ In the report, not surprisingly, emphasis is placed on the continued use of Alberta's vast coal resources for the generation of electricity.

Dovetailing with their policy statements on CCS, the "federal and provincial Governments have committed a total of approximately \$3 billion in funding for CCS” projects through a

Government of Alberta, CCS Major Initiatives (4 August 2011), online: ADOE <http://www.energy. alberta.ca/Initiatives/1897.asp>.

SA 2009, C-2.5 [CCSFA].

ACCSDC Final Report, supra note 10 at 16.

Government of Alberta, Launching Alberta's Energy Future: Provincial Energy Strategy (December 2008 at 2, online: $\mathrm{ADOE}<$ http://www.energy.alberta.ca/Org/pdfs/AB_ProvincialEnergyStrategy.pdf $>$ [Provincial Energy Strategy].

Ibid.

Ibid.

Ibid.

Ibid. 
number of federal and provincial programs. ${ }^{59}$ To date, CCS projects which have received federal and provincial funding commitments include:

(1) The \$1.4 billion SaskPower Boundary Dam Project in Estevan, Saskatchewan, "which will be one of the world's first and largest full-scale CCS demonstrations at a coal-fired power plant”;

(2) The TransAlta Pioneer Project at the Keephills 3 Plant near Edmonton "which could capture as much as one million tonnes of $\mathrm{CO}_{2}$ per year beginning in 2015”;

(3) The Quest Project, a joint initiative by Shell Canada, Chevron Canada Ltd, and Marathon Oil Sands LP, which proposes to integrate CCS capture infrastructure into Shell's Scotford Oil Sands upgrader near Edmonton and transport $\mathrm{CO}_{2}$ by pipeline to be injected into a saline aquifer, which could lead to the reduction of up to 1.2 megatonnes (Mt) of GHG emissions annually;

(4) The Enhance Energy and Northwest Upgrading Project, which involves the construction of a 240-kilometre $\mathrm{CO}_{2}$ pipeline system, the Alberta Carbon Trunk Line, to "greatly increase the capacity for future [CCS] projects" in Alberta; and

(5) The Swan Hills Project, a coal gasification project that will convert coal into a synthetic gas for generating clean electricity and capture up to 1.3 million tonnes of $\mathrm{CO}_{2}$ per year "to enhance the recovery of conventional oil in the area."60

\section{Pre-CCS Statutes Amendment Act Regulatory History}

Prior to the passage of the CCS Statutes Amendment Act, and in the absence of an articulated CCS legislative and regulatory framework, CCS projects were regulated under a variety of legislation and Energy Resources Conservation Board (ERCB or the Board) Directives governing other analogous projects. ${ }^{61}$ These included acid gas disposal (AGD), natural gas storage, and enhanced oil recovery (EOR) schemes. CCS regulation was possible under the analogous legislation and Directives since each of the CCS stages, apart from the long-term post-abandonment monitoring stage, also exist in these analogous projects.

For example, capture and separation processes are used by oil and gas facilities as well as chemical processing facilities. Large-scale $\mathrm{CO}_{2}$ transportation systems are used for EOR operations. Gas is injected in connection with underground storage of natural gas and AGD

$59 \quad$ Canada's Action on Climate Change, supra note 24.

60 Ibid. Other projects receiving federal investments include: the Husky Oil Project in Lloydminster, Saskatchewan "to develop knowledge in $\mathrm{CO}_{2}$ sequestration in heavy oil reserves"; the ARC Resources Project near Edmonton "to demonstrate safe storage in deep saline aquifers”; the Spectra Energy Project at its sour gas processing plant in Fort Nelson, British Columbia that "could lead to emissions reductions of 2 Mt per year"; the "engineering and design study by EPCOR looking into the feasibility of an integrated gasification combined cycle (IGCC) power plant at its Genesee site near Edmonton”; and the Petroleum Technology Research Centre Aquistore feasibility project. Government of Alberta, News Release, “Carbon Capture and Storage (CCS) project details” (8 October 2009), online: Government of Alberta <http://alberta.ca/ACN/200910/270703512366B-9522-07D4-3AD4E71EE1B8F5A7.html>.

61 See e.g. ERCB, Directive 065: Resources Applications for Oil and Gas Reservoirs (Calgary: ERCB, 2010) [Directive 065]. ERCB Directives are available online at <http://www.ercb.ca $>$. 
schemes. ${ }^{62}$ Abandonment procedures are used in oil and gas operations and other large-scale operations. ${ }^{63}$

The ERCB has approximately " 25 years of experience with acid gas re-injection and small-scale $\mathrm{CO}_{2}$ transportation." ${ }^{64}$ As a result, a regulatory framework existed well before the CCS Statutes Amendment Act which addressed and managed most stages of CCS development, including "public safety, environmental protection and resource conservation. ${ }^{, 65}$

Despite the analogy between AGD and CCS, the sheer size of CCS projects requires that long-term monitoring protocols absent in the AGD regulatory regime be established for CCS projects. While the risks associated with CCS may be lower than those associated with AGD, given the significantly more hazardous properties of hydrogen sulfide $\left(\mathrm{H}_{2} \mathrm{~S}\right)$, the large size of CCS projects has the potential to occasion lateral migration issues that "will be far more significant than the migration issues associated with the disposal of relatively small volumes of acid gas. ${ }^{, 66}$ Unfortunately, due to the size and unique nature of CCS projects, using existing regulations and ERCB Directives is not straightforward.

Prior to the CCS Statutes Amendment Act, the ERCB regulated CCS development under three categories: (1) sequestration/disposal; (2) storage; and (3) use in EOR schemes. Each of the three categories has its own separate regulatory framework, although there is some overlap between them. ${ }^{67}$ As addressed in Part $\mathrm{V}$ of this article, much of the regulatory regime applicable to processes analogous to CCS, which existed prior to the CCS Statutes Amendment Act, has survived the enactment of that legislation.

\section{THE CCS STATUTES AMENDMENT ACT AND THE CS TENURE REGULATION}

The CCS Statutes Amendment Act has three main objectives - to clarify the ownership of pore space, to transfer to the province long-term liability for injected $\mathrm{CO}_{2}$ post-closure, and to create a stewardship fund to be used for remedial and ongoing monitoring costs for injected $\mathrm{CO}_{2}{ }^{68}$ These objectives have been carried out by way of amendments to the MMA, OGCA, ERCA, PLA, and SRA, as set out in the CCS Statutes Amendment Act. Of the amendments to the $M M A$, of particular significance are the following: (1) title to pore space in all lands in Alberta, apart from federally owned lands, has been vested in the Crown in right of Alberta; (2) a regime for the disposition of pore space for sequestration purposes has been created; (3) a framework for transferring long-term liability from the CCS operator to

AGD schemes are analogous to CCS since they both entail the permanent disposal of waste streams. See generally Stefan Bachu, "Legal and Regulatory Challenges in the Implementation of $\mathrm{CO}_{2}$ Geological Storage: An Alberta and Canadian Perspective” (2008) 2:2 International Journal of Greenhouse Gas Control 259 at 260.

ACCSDC Final Report supra note 10 at 12.

Ibid.

Bankes \& Poschwatta, supra note 12 at 4.

Alberta Carbon Capture and Storage Development Council, Accelerating Carbon Capture and Storage in Alberta: Interim Report (30 September 2008) at 20, online: ADOE <http://www.energy.alberta. ca.org/pdfs/CCSInterimRept.pdf> [ACCSDC Interim Report].

Government of Alberta, News Release "Amendments guide use of carbon capture and storage technology” (1 November 2010), online: ADOE <http://energy.alberta.ca/>. 
the Crown has been developed; and (4) a fund to support specified costs arising from $\mathrm{CO}_{2}$ sequestration has been created. Pursuant to sections 5 and 7 of the amended MMA, the Lieutenant Governor-in-Council enacted the CS Tenure Regulation which: (1) defines pore space $;^{69}(2)$ establishes the term for permits and leases; ${ }^{70}(3)$ limits the size of land for permits and leases and sets the annual rental fee $;^{71}(4)$ establishes a minimum depth for the injection of $\mathrm{CO}_{2} ;{ }^{72}$ and (5) creates the requirement for monitoring, measurement and verification plans and closure plans, which must be approved by the Minister and updated every three years. ${ }^{73}$ The key aspects of the MMA amendments and the CS Tenure Regulation are addressed in further detail below.

\section{A. OWNERSHIP OF STORAGE DOMAIN AND DiSPOSITION REGIME}

The new section 15.1(1) of the MMA declares that: (1) "no grant from the Crown of any land, ... or mines or minerals in any land in Alberta, has operated or will operate as a conveyance of the title to the pore space" below the surface of that land; (2) "the pore space below the surface of all land in Alberta is vested in and ... remains the property of the Crown in right of Alberta," whether or not the MMA or an agreement issued under the MMA grants rights in respect of a subsurface reservoir (for example, storage rights) or minerals occupying a subsurface reservoir (for example, mineral rights), whether or not "minerals or water is produced, recovered or extracted from a subsurface reservoir”; and (3) Crown title to pore space "is deemed to be an exception contained in the original grant from the Crown for the purposes of section 61(1) of the Land Titles Act."74 Section 15.1(1) of the MMA is declaratory and therefore retroactive. As a result, the Crown purportedly is, and always has been, the owner of all the pore space in Alberta, regardless of who owns the storage or mineral rights. Section 15.1(1) has the effect of endorsing Crown title to pore space on every certificate of title in Alberta.

Pursuant to section 15.1(2) of the MMA, the declaration of ownership in section 15.1(1) does not affect the title to land that, on the date on which the section came into force, belonged to the Crown in right of Canada. Sections 15.1(4) and (5) are far reaching, deeming that Alberta's ownership of pore space does not amount to an expropriation for any purpose, including for the purposes of the Expropriation Act. ${ }^{75}$ Further, no person has a right of action or may commence or maintain proceedings against the Crown to claim damages, compensation, or a declaration of any kind, as a result of Alberta's declared ownership of pore space under section 15.1. ${ }^{76}$

The disposition of the rights for the "use" of pore space falls within the administration of Alberta Energy. ${ }^{77}$ In accordance with section 15.1(3) of the MMA, the "Minister of Energy may enter into agreements with respect to the use of pore space.” Section 1(i) of the CS

Supra note 3, s 1(i).

Ibid, ss 4, 10.

Ibid, ss 5,12 .

Ibid, s 1(c).

Ibid, ss 7, 15-16, 18-19.

MMA, supra note 4, s 15.1, as amended by CCS Statutes Amendment Act, supra note 1, s 2(6); Land Land Title Act, RSA 2000, c L-4.

RSA 2000, c E-13.

MMA, supra note 4, s 15.1(5), as amended by CCS Statutes Amendment Act, supra note 1, s 2(6).

MMA, ibid, s 2(a), as amended by CCS Statutes Amendment Act, ibid., s 2(3). 
Tenure Regulation defines "pore space" as "the pores contained in, occupied by or formerly occupied by minerals or water below the surface of land." "Subsurface reservoir" is defined in the MMA as "the pore space within an underground formation or a subsurface cavern."78 The CS Tenure Regulation further defines “deep subsurface reservoir," in respect of a sequestration permit or lease, as "the pore space within an underground formation that is deeper than 1000 metres below the surface of the land within the location of that permit or lease.”79 In short, the storage domain contemplated for $\mathrm{CO}_{2}$ sequestration consists of pore space contained in, occupied by, or formerly occupied by, minerals or water within an underground formation deeper than 1,000 metres below the surface of the land allocated.

An amendment to section 16 of the $M M A$ provides the general procedure for disposition of subsurface rights. Subject to the $M M A$, its regulations, and any express provision in any applicable regional plan that limits mineral development in a geographic area, the Minister may

issue an agreement in respect of a ... subsurface reservoir

(a) on application, if the Minister considers the issuance of the agreement warranted in the circumstances,

(b) by way of sale by public tender conducted in a manner determined by the Minister, or

(c) pursuant to any other procedure determined by the Minister. ${ }^{80}$

Under the $M M A$, “agreement” has been redefined to include an instrument issued pursuant to the $M M A$ or its predecessor legislation that grants rights "in respect of a mineral or subsurface reservoir." "11 “Agreement” expressly excludes other arrangements with the Crown, such as a notification in section 13, a transfer referred to in section 12, a unit agreement referred to in section 102 or a contract referred to in section 9(a) of the $M M A{ }^{82}$

The CCS Statutes Amendment Act introduces a new Part 9 (sections 114 to 124) to the $M M A$, entitled "Sequestration of Captured Carbon Dioxide." 83 "Carbon capture and storage project" is defined as "a project for the injection of captured carbon dioxide conducted pursuant to rights granted under an agreement under Part 9 of the [MMA]". 84 "Sequestration" is defined as "permanent disposal." 85

MMA, ibid, s 1(1)(bb), as amended by CCS Statutes Amendment Act, ibid, s 2(2)(d). "Subsurface cavern means a subsurface space created as a result of operations for the recovery of a mineral” (MMA, ibid, s 1(1)(aa).

CS Tenure Regulation, supra note 3, s 1(c).

MMA, supra note 4, s 16, as amended by CCS Statutes Amendment Act, supra note 1, s 2(7).

MMA, ibid, s 1(1)(a), as amended by CCS Statutes Amendment Act, ibid, s 2(2)(a).

MMA, ibid.

CCS Statutes Amendment Act, supra note 1, s 2(18).

ERCA, supra note 6, s 1(a.1), as amended by CCS Statutes Amendment Act, ibid, s 1(2). "Captured carbon dioxide" is defined as "a fluid substance consisting mainly of carbon dioxide captured from an emissions source." MMA, supra note 4, s 1(1)(a.1), as amended by CCS Statutes Amendment Act, ibid, s 2(2)(b).

85 MMA, ibid, s 1(1)(y.1), as amended by CCS Statutes Amendment Act, ibid, s 2(2)(c). 
The new Part 9 of the MMA provides for two specific types of agreements: (1) agreements "to evaluate the geological or geophysical properties of a subsurface reservoir in a location to determine its suitability for use for the sequestration of captured carbon dioxide," ${ }^{\prime \prime 6}$ issued in the form of "evaluation permits",;7 and (2) agreements "to inject captured carbon dioxide into a subsurface reservoir for sequestration," ${ }^{88}$ issued in the form of a "carbon sequestration lease." ${ }^{89}$ These agreements may be entered into notwithstanding section 57 of the MMA, which grants storage rights to mineral owners. They are not transferable without the written consent of the Minister, and the Minister may, in his or her discretion, refuse to consent to a transfer of the agreement. ${ }^{90}$

In addition, by way of amendment to section 9(a) of the $M M A$, "the Minister, on behalf of the Crown in right of Alberta and with the authorization of the Lieutenant Governor in Council may enter into a contract with any person or the government of Canada or of a province or territory respecting the storage or sequestration of substances in subsurface reservoirs." 91 These contracts may be entered into notwithstanding anything in the MMA or any regulation or agreement. ${ }^{92}$ "Contract" is not defined in the MMA.

An issue that arises in connection with the disposition of sequestration rights is how the Crown's disposition of those rights aligns with the subsurface "storage rights" of mineral owners under section 57 of the MMA. "Storage right" is defined under the MMA as a "right to inject fluid mineral substances into a subsurface reservoir for the purpose of storage."93 The rights as defined are limited to storage and may not include the right to inject for other purposes unless specifically authorized. For example, the owner of a storage right arguably does not have the right to inject fluid mineral substances for the purpose of EOR or repressurization, unless authorized by the ERCB pursuant to section 56 of the MMA.

A potential priority issue exists among: (1) agreements for the "use” of pore space granted by the Minister under the section 15.1(3) of the MMA; (2) agreements for evaluation or sequestration granted under new Part 9 of the $M M A$; (3) contracts granted under section 9(a) of the MMA; and (4) storage rights of mineral owners under section 57 of the MMA. Of note is the Minister of Energy's statement that the CCS Statutes Amendment Act does not in any way alter the ownership of mines and mineral resources and does not affect activities such as EOR. ${ }^{94}$ As well, the ERCB

MMA, ibid, s 115(1). Note that exploration of a subsurface reservoir for the general purpose of injecting substances is governed by Part 8 of the MMA. See MMA, ibid, s 106(b)(i), as amended by CCS Statutes Amendment Act, ibid, s 2(17). The Lieutenant Governor-in-Council may make regulations respecting the exploration for subsurface reservoirs (MMA, ibid, s 108), and "development and operation of injection wells and facilities and any other matters incidental to the use of subsurface reservoirs.” $M M A$, ibid, s 5(1)(a), as amended by CCS Statutes Amendment Act, ibid, s 2(4)(a).

See CS Tenure Regulation, supra note 3, ss 1(e), 3.

MMA, supra note 4, s 116(1).

See CS Tenure Regulation, supra note 3, ss 1(b), 9.

MMA, supra note 4, ss 118.

MMA, ibid, s 9(a)(iii), as amended by CCS Statutes Amendment Act, supra note 1, s 2(5).

Ibid.

Ibid, s 1(1)(z).

Alberta, Legislative Assembly, Hansard, 27th Leg, 3rd Sess (3 November 2010) (Hon Kenneth R Kowalski) at 1099. The process for, and content of, applications for evaluation and sequestration leases pursuant to Part 9 will be established by regulations granted pursuant to section 124 of the MMA. 
may not approve a scheme ... pursuant to an agreement under Part 9 of the Mines and Minerals Act unless the lessee of that agreement satisfies the Board that the injection of the captured carbon dioxide will not interfere with

(a) the recovery or conservation of oil or gas, or

(b) an existing use of the underground formation for the storage of oil or gas. ${ }^{95}$

Under the CS Tenure Regulation, the procedure for the grant of an evaluation permit and a carbon sequestration lease includes the submission of: (1) "an application in a form that is satisfactory to the Minister"; ${ }^{96}$ (2) the prescribed application fee $;^{97}$ (3) the prescribed annual rental for the first year of the term of the evaluation permit; and (4) a monitoring, measurement, and verification plan. ${ }^{98}$ Additional requirements in the case of carbon sequestration leases are the submission of: (5) "evidence satisfactory to the Minister that the location specified in the application is suitable" for the sequestration of captured carbon dioxide; and (6) a closure plan. ${ }^{99}$

In the case of evaluation permits, the monitoring, measurement, and verification plan must set out:

(a) the monitoring, measurement and verification activities that the permittee will undertake for the term of the permit,

(b) $\ldots$ an analysis of the likelihood that the operations or activities ... will interfere with mineral recovery, and

(c) $\ldots$ any other information requested by the Minister. ${ }^{100}$

In the case of a carbon sequestration lease, the monitoring, measurement, and verification plan must, in addition to the above requirements, include "an analysis of the likelihood that the operations or activities will interfere with mineral recovery, based on the geological interpretations and calculations the lessee is required to submit to the Board pursuant to Directive 65 in its application for approval of the injection scheme under the [OGCA]."101

A closure plan for carbon sequestration leases may be approved if it "sets out a description of the activities satisfactory to the Minister that the lessee will undertake to close down sequestration operations and facilities." 102 Of particular note is that, for carbon sequestration leases, both the monitoring, measurement, and verification plan, and the closure plan, have an expiration. Both plans expires on the earlier of: (1) "the third anniversary of the date on

OGCA, supra note 5, s 39(1.1), as amended by CCS Statutes Amendment Act, supra note 1, s 3(6). CS Tenure Regulation, supra note 3, ss 3(2)(a), 9(2)(a).

See Mines and Minerals Administration Regulation, AR 262/97, Schedule.

CS Tenure Regulation, supra note 3, ss 3(2)(b)-(d), 9(2)(b)-(d).

Ibid, ss 9(2)(e)-(f).

Ibid, s 7.

Ibid, s 15(b).

Ibid, s 18. 
which the plan was approved"; or (2) the date of renewal of the lease. ${ }^{103}$ In both cases, the lessee is required to submit a new plan for approval no less than 90 days before the expiry date. ${ }^{104}$ There is also a reporting requirement - each year before the anniversary date of the plan, the lessee must report its findings and observations from the monitoring, measurement, and verification activities that have been conducted. ${ }^{105}$

The CS Tenure Regulation allows an applicant of more than one permit or lease to apply to the Minister for the grouping of permits or leases for the purpose of submitting only one monitoring, measurement, and verification plan in respect of all of the permits or leases in the approved group. However, the location of all the permits and leases within a group "must be contiguous." 106 The area of land for an evaluation permit or a carbon sequestration lease must not exceed 73,728 hectares. ${ }^{107}$ The annual rental for each year of the term for either an evaluation permit or a carbon sequestration lease is $\$ 1.00$ per hectare in the area of the location of the permit or lease, subject to a minimum of $\$ 50$ per year. ${ }^{108}$

The term of an evaluation permit is five years from the commencement date shown in the permit, and the term of a carbon sequestration lease is 15 years. ${ }^{109}$ However, the "Minister may renew a carbon sequestration lease for further terms of 15 years” upon application for renewal by the lessee, who is required to submit a further monitoring, measurement, and verification plan, and a closure plan with evidence that the lessee "has the approval of the Board under section 39 of the Oil and Gas Conservation Act for the injection of the captured carbon dioxide in the location of the lease."110

Any subsequent closure plan, including the closure plan for renewal of the lease, may be approved if it contains:

(a) A summary of the activities that have been conducted by the lessee on the location of the carbon sequestration lease since it was issued;

(b) The quantity of captured carbon dioxide that has been injected;

(c) An evaluation of whether the injected captured carbon dioxide has behaved in a manner consistent with the geological interpretations and calculations the lessee submitted to the Board pursuant to Directive 65 in its application for approval of the injection scheme under the Oil and Gas Conservation Act;

(d) The most recent geological interpretations and calculations ... made by the lessee with respect to the injected carbon dioxide and any associated pressure front;

(e) A description of the location, condition, plugging procedures and integrity testing results for every well that has been used for the injection of captured carbon dioxide under the lease;

Ibid, s 16(1).

Ibid, ss 16, 19.

Ibid, s 17(2).

Ibid, ss 8,14 .

Ibid, ss 5(1), 12(1).

Mines and Minerals Administration Regulation, supra note 97.

CS Tenure Regulation, supra note 3, ss 4, 10.

Ibid, s 11(1)(d). 
(f) A description of any decommissioning, abandonment or reclamation activities undertaken by the lessee in the location of the lease;

(g) An inventory of the reports and documents that the lessee has submitted to the Board or [to an Alberta or federal government] department or agency ... since the approval of the first closure plan related to the carbon sequestration lease, whether or not those reports and documents were required to be submitted; [and]

(h) Advice and recommendations about the monitoring, measurement and verification activities that should be conducted after the issuance of a closure certificate issued for the carbon sequestration lease under section 120 of the Act. ${ }^{111}$

\section{B. LONG-TERM LIABILITY REGIME}

Under the new Part 9 of the MMA, the Crown will assume long-term liability for projects involving the sequestration of captured $\mathrm{CO}_{2}$. Projects involving the storage of $\mathrm{CO}_{2}$ for other purposes do not fall within the purview of Part 9, regardless of the duration of storage. The new section 121 of the MMA addresses significant issues which include when the Crown will assume liability and the types of liabilities that will be assumed.

The Crown will assume liability when the Minister issues a "closure certificate" to a lessee in respect of a project under Part 9. ${ }^{112}$ The only time the Crown will assume liability of sequestered $\mathrm{CO}_{2}$ prior to the issuance of a closure certificate is when the lessee ceases to exist before closure. ${ }^{113}$ In such cases, the ERCB has the authority to designate the wells, facilities, or sites used by a lessee for the injection of captured $\mathrm{CO}_{2}$ as orphan wells, facilities, or sites. The ERCB may also deem a lessee to be a defaulting working interest participant if: (1) the lessee has an obligation to contribute toward reclamation costs under the OGCA; (2) the lessee "has not contributed to those costs as required"; and (3) in the opinion of the Board, the lessee "does not exist, cannot be located or does not have the financial means to contribute to those costs."114

The criteria for the issuance of a closure certificate are set out in the new section 120(3) of the MMA:

(a) the lessee has [monitored "all wells and facilities and has performed all closure activities in accordance with the regulations" ${ }^{115}$ ];

(b) the lessee has abandoned all wells and facilities in accordance with the requirements under the Oil and Gas Conservation Act and the regulations under [Part 9];

Ibid, s 19(3).

MMA, supra note 4, s 121(1).

Ibid, s 121(3).

Ibid, s 123(1).

Ibid, s 119. 
(c) the lessee has complied with the reclamation requirements under the Environmental Protection and Enhancement Act"; ${ }^{116}$

(d) the closure period specified in the regulations has passed;

(e) the conditions specified in the regulations have been met; and

(f) the captured carbon dioxide is behaving in a stable and predictable manner, with no significant risk of future leakage. $^{117}$

Upon the issuance of a closure certificate, the Minister must "notify the Board and any other person required by the regulations." ${ }^{118}$ Certain of these criteria, including the closure period and the conditions for a closure certificate to be issued, have not yet been established by regulation. Upon issuing a closure certificate to a lessee under a Part 9 agreement, the Crown

becomes the owner of the captured carbon dioxide injected pursuant to the agreement [and] ... assumes all obligations of the lessee:

(i) as owner and licensee under the Oil and Gas Conservation Act;

(ii) as the person responsible for the injected captured carbon dioxide under the Environmental Protection and Enhancement Act;

(iii) as the operator under Part 6 of Environmental Protection and Enhancement Act in respect of the land within the location of the agreement used by the lessee in relation to the injection of captured carbon dioxide; and

(iv) under the Surface Rights Act. ${ }^{119}$

Upon issuing a closure certificate, the lessee is also released from any obligations under section 56(2)(a) of the MMA to indemnify the Crown. ${ }^{120}$ The release is effective with respect to the wells "used by the lessee in relation to the injection of captured carbon dioxide." ${ }^{\text {"In }}$ In these instances, the lessee is indemnified by the Crown against liability for damages in any tort action brought by another party if:

(a) the liability is attributable to an act done or omitted to be done by the lessee in the lessee's exercise of rights under the agreement in relation to the injection of captured carbon dioxide; and

(b) any other conditions specified in the regulations are met. ${ }^{122}$

RSA 2000, с E-12 [EPEA].

MMA, supra note 4, s $120(3)$.

Ibid, ss 120(4), 121(4).

Ibid, ss 121(1)(a)-(b).

Ibid, s 121(1)(c). The indemnification is for loss suffered by the Crown in respect of any claims made by reason of anything done in using a well or drilling a well for injection under section 56(1).

122 Ibid, ss 121(2)(a)-(b). 
In accordance with the new section 23.1 of the OGCA, where the ERCB receives notice issued by the Minister under Part 9 of the MMA that the Crown has assumed liability, the ERCB must "amend the licence or approval to reflect that the Crown is the holder of the licence ... or the approval holder for that scheme.”123 The former holder of the licence or approval for the well, facility, or scheme is relieved from all obligations under the OGCA with respect to the well, facility, or scheme, except as to any outstanding debts to the ERCB. $^{124}$

\section{CCS FUND}

The CCS Statutes Amendment Act makes provision for the funding of certain obligations assumed by the Crown. The Orphan Fund established under the OGCA does not apply to any facility or well used in connection or associated with the disposal of captured $\mathrm{CO}_{2}$ pursuant to an agreement under Part 9 of the $M M A .{ }^{125}$ The new section 122 of the MMA establishes a Post-closure Stewardship Fund, similar to the Orphan Fund, into which fees must be paid by CCS operators in accordance with the regulations (which have yet to be made). ${ }^{126}$ "The Fund is to be held and administered by the Minister in accordance with [the MMA and] the regulations.... The Minister may make payments out of the Fund for the purposes [designated in section $122(2)$ of the $M M A$ and] ... must maintain a separate accounting record of the Fund.”127 The Post-closure Stewardship Fund may be used for the purposes of: (a) monitoring the behaviour of captured $\mathrm{CO}_{2}$ that has been injected pursuant to an agreement under Part 9 of the $M M A$; (b) fulfilling any statutory obligations assumed by the Crown under section 121(1)(b) of the MMA; (c) "paying for suspension costs, abandonment costs and related reclamation or remediation costs in respect of orphan facilities where the work is carried out by the Board, by a person authorized by the Board, or by a Director or a person authorized by a Director in accordance with the Environmental Protection and Enhancement Act"; (d) "paying for costs incurred in pursuing reimbursement for the costs referred to in ... (c) from the lessee responsible for paying them;" and (e) "for any other purpose prescribed in the regulations." 128 Any costs incurred by the Crown as a result of the release of obligations by the lessee to indemnify the Crown under section 56(2)(a) of the MMA, and any third party liability indemnity claims, are not covered by the Post-closure Stewardship Fund.

Where the Minister makes a payment from the Post-closure Stewardship Fund to a third party "in respect of a defaulting working interest participant's share of suspension, abandonment or reclamation costs, the defaulting working interest participant is not released from any liability under [the MMA] in respect of those costs." ${ }^{129}$ Section 123(2)(b) precludes double recovery by the third party and states that "if the person who receives the payment later recovers all or a part of the costs from the defaulting working interest participant, the

\footnotetext{
123 OGCA, supra note 5, s 23.1, as amended by CCS Statutes Amendment Act, supra note 1, s 3(5). Ibid.

OGCA, ibid, ss 68(d)(vii.3), (g.1), as amended by CCS Statutes Amendment Act, ibid, s 3(8). MMA, supra note 4, s 122(3). CS Tenure Regulation, supra note 3, s 20, states: "A lessee shall pay into the Post-closure Stewardship Fund a fee per tonne of captured carbon dioxide injected into the location of a carbon sequestration lease at the rate established by the Minister.” MMA, ibid, ss 122(4)-(8).

MMA, ibid, s 122(2).

Ibid, s 123(2)(a).
} 
person shall forthwith pay to the Minister an amount equal to the amount recovered, less the reasonable costs of recovery as determined by the Minister.”130

\section{REgulation}

The ERCB has the responsibility to issue approvals and licences for CCS projects. ${ }^{131}$ Where charged with the conduct of a hearing, inquiry or other investigation in respect of a proposed CCS project, the ERCB must, "in addition to any other matters it may or must consider in conducting the hearing, inquiry or other investigation, give consideration to whether the project is in the public interest, having regard to the social and economic effects of the project and the effects of the project on the environment.”132 The ERCB may approve a CCS scheme under section 39(1)(d) of the OGCA "on any terms and conditions that the Board prescribes.” However, as previously mentioned, the ERCB may not approve a scheme pursuant to an agreement under Part 9 of the $M M A$ "unless the lessee of that agreement satisfies the Board that the injection of the captured carbon dioxide will not interfere with

(a) the recovery or conservation of oil or gas, or

(b) an existing use of the underground formation for the storage of oil or gas. ${ }^{133}$

During the operation of the scheme, the ERCB has the power to "take any means that appear to it to be necessary or expedient in the public interest to prevent or control the flow or escape" of oil, gas, water, or any other substance from a facility, or from a well or any underground formation that the well enters, if not prevented or controlled. ${ }^{134}$ The ERCB is also "entitled to enter on and inspect any well, or any place used or occupied in connection with a well, that is used for the storage or disposal of any substance to an underground formation." 135 The ERCB is authorized to make regulations regarding CCS projects, including: (1) "measures to be adopted to confine any injected fluid or other substance to the underground formation into which it is injected"; 136 (2) measures "prohibiting the drilling through underground formations used for storage or disposal of substances without taking adequate measures to confine the injected substances to those formations"; and (3) "measures to be taken before the commencement of drilling and during drilling to confine substances likely to be encountered in an underground formation used for storage or disposal of substances." 137

The ERCB and the Alberta Department of Energy (ADOE) have been given joint jurisdiction over CCS projects. Historically there has been a separation of powers between

Ibid, s 123(2)(b).

MMA, ibid, ss 115(2), 116(2). The new section 2(e.1) adds to the purposes of the ERCA "to secure the observance of safe and efficient practices in the exploration for and use of underground formations for the injection of substances.” ERCA, supra note 6, s 2(e.1), as amended by CCS Statutes Amendment Act, supra note 1, s 1(3). A similar amendment is made to the purposes of the OGCA in section 4(b) to add the phrase "the storage or disposal of substances." OGCA, supra note 5, s 4(b), as amended by CCS Statutes Amendment Act, ibid, s 3(3).

ERCA, ibid, s 3, as amended by CCS Statutes Amendment Act, ibid, s 1(4).

OGCA, supra note 5, s 39(1.1), as amended by CCS Statutes Amendment Act, ibid, s 3(6).

OGCA, ibid, s 41(1), as amended by CCS Statutes Amendment Act, ibid, s 3(7).

OGCA, ibid, s 96(1)(b.1), as amended by CCS Statutes Amendment Act, ibid, s 3(9).

OGCA, ibid, s 10(1)(w), as amended by CCS Statutes Amendment Act, ibid, s 3(4)(b).

OGCA, ibid, ss 10(1)(x.1)-(x.2), as amended by CCS Statutes Amendment Act, ibid, s 3(4)(c). 
the ADOE, acting on behalf of the province as owner of Crown-owned oil and gas interests, and the ERCB, which has assumed an arm's-length regulatory function. ${ }^{138}$ Joint jurisdiction therefore raises the question why the ADOE has assumed what is essentially a regulatory function in respect of CCS projects in Alberta. ${ }^{139}$

An example of the increasing scope of ADOE regulatory function is that the Minister or a person designated by the Minister may, "from time to time or on a periodic basis, conduct an investigation or inspection in relation to ... any well, installation, equipment or other facility used or formerly used for or in connection with the injection of a substance into a subsurface reservoir for the purpose of storage or sequestration." ${ }^{140}$ Further, the Minister, at the beginning of and during sequestration operations, is in charge of approving monitoring, measurement, and verification plans and closure plans, as well as approving closure and issuing a closure certificate. ${ }^{141}$ The lessee also reports to the Minister, on an annual basis, "findings and observations from the monitoring, measurement and verification activities that the lessee has conducted." 142 In this sense, the ADOE appears to have some degree of regulatory powers at the commencement of and during operations, and at the closure of sequestration schemes. The reason for this overlap is not clear. ${ }^{143}$

\section{Post-CCS Statutes Amendment Act Regulatory Framework}

Given the high level of interest in CCS development and the absence of any CCS-specific ERCB Directives, on 29 June 2010 the ERCB released Bulletin 2010-22, which provides CCS applicants with guidance on the procedure the ERCB intends to use when processing applications for the development and operation of CCS projects in Alberta. ${ }^{144}$ Although created prior to the passage of the CCS Statutes Amendment Act, certain aspects of Bulletin 2010-22 continue to apply. In Bulletin 2010-22, reference is made to: (1) Directive 056: Energy Development Applications and Schedules; ${ }^{145}$ (2) Directive 065: Resources Applications for Conventional Oil and Gas Reservoirs; ${ }^{146}$ (3) Directive 051: Injection and Disposal Wells - Well Classifications, Completions, Logging, and Testing Requirements; ${ }^{147}$ (4) the Pipeline Act ${ }^{148}$ and Pipeline Amendment Regulation, ${ }^{149}$ (5) Directive 007: Volumetric and Infrastructure Requirements; ${ }^{150}$ (6) Directive 017: Measurement Requirements for Oil

Nigel Bankes, “Alberta makes significant progress in establishing a legal and regulatory regime to accommodate carbon capture and storage (CCS) projects” Ablawg.ca (3 November 2010) at 4, online: Ablawg.ca <http://ablawg.ca/wp-content/uploads/2010/11/blog_nb_ccsnov2010.pdf>.

Ibid.

MMA, supra note 4, s 52(1(b), as amended by CCS Statutes Amendment Act, supra note 1, s 2(11).

CS Tenure Regulation, supra note 3, ss 7, 15, 18.

Ibid, s 17(2).

Bankes, supra note 138 at 4-5.

ERCB, Bulletin 2010-22: "ERCB Processes Related to Carbon Capture and Storage (CCS) Projects” (29 June 2010) [Bulletin 2010-22]. See ACCSDC Final Report, supra note 10 at 49; ACCSDC Interim Report, supra note 67 at 21.

ERCB, Directive 056: Energy Development Applications and Schedules, (Calgary: ERCB, 2008) [Directive 056].

Supra note 61.

ERCB, Directive 051: Injection and Disposal Wells - Well Classifications, Completions, Logging, and Testing Requirements (Calgary: ERCB, 1994) [Directive 051].

RSA 2000, с P-15.

Alta Reg 84/2009.

ERCB, Directive 007: Volumetric and Infrastructure Requirements (Calgary: ERCB, 2007) [Directive 007]. 
and Gas Operators; ${ }^{151}$ (7) Directive 071: Emergency Preparedness and Response Requirements for the Petroleum Industry; ${ }^{152}$ and (8) Directive 020: Well Abandonment. ${ }^{153}$ The principal regulatory processes are set out below.

\section{A. ERCB ENERGY DEVELOPMENT APPLICATION (DIRECTIVE 056) AND $\mathrm{CO}_{2}$ DisPosal SCHEME APPLICATION (DIRECTIVE 065)}

In addition to site-specific or project-specific information which may be required to address public interest issues, Directive 056 and Directive 065 "set out the key application requirements for prospective developers of CCS projects with respect to transportation of $\mathrm{CO}_{2}$ via pipelines and $\mathrm{CO}_{2}$ disposal to underground geologic formations." "154 "Directive 056 sets out the requirements and procedures ... [for the] licensing of a $\mathrm{CO}_{2}$ disposal well, including a participant involvement program.”155

Unit 4 of Directive 065 covers the requirements and procedures "for approval of disposal of fluids containing $\mathrm{CO}_{2}$. Section 4.2 of Directive 065 sets out application requirements specific to [AGD] ( $\mathrm{CO}_{2}$ is an acid gas). Directive 065, Unit 2 also covers enhanced recovery schemes, which may be connected to carbon capture facilities."156

\section{B. Monitoring, RePorting, AND SAFETY}

Directive 007 and Directive 017 set out "general requirements and procedures for measurement" and reporting. ${ }^{157}$ Directive 065 "provides the mechanism for proposing methods of monitoring and reporting injected $\mathrm{CO}_{2}$ volumes, pressures, composition, and other pertinent data (in addition to standard volumetric reporting via the Petroleum Registry of Alberta)." ${ }^{158}$ The Pipeline Regulation lists pipeline monitoring and reporting requirements, and Directive 071 sets out emergency safety procedures and "protocols that the ERCB expects operators to have in place and be able to demonstrate before commencing CCS operations. The majority of project-specific operating conditions, monitoring, and reporting requirements will be set out in the scheme approval documents.”159

\section{Closure - Suspension, Abandonment, AND Reclamation}

Directive 020 "sets out the requirements for abandonment, casing removal, zonal abandonments, and plug backs in wells." 160 The Pipeline Act and the Pipeline Regulation "prescribe the requirements for pipeline discontinuation and abandonment.... Additional well or scheme abandonment requirements may be specified in [the] scheme approval

ERCB, Directive 017: Measurement Requirements for Oil and Gas Operators (Calgary: ERCB, 2009) [Directive 017].

ERCB, Directive 071: Emergency Preparedness and Response Requirements for the Petroleum Industry (Calgary: ERCB, 2008) [Directive 071].

ERCB, Directive 020: Well Abandonment (Calgary: ERCB, 2010) [Directive 020].

Bulletin 2010-22, supra note 144 at 1.

Ibid.

Ibid at 2 .

Ibid.

Ibid.

Ibid.

Ibid. 
documents. Surface reclamation criteria, including those for $\mathrm{CO}_{2}$ disposal schemes," are the responsibility of Alberta Environment. ${ }^{161}$

\section{REgUlATORY GAPS}

Bulletin 2010-22 requires compliance with other ERCB regulations not identified specifically in the Bulletin, as well as legislation, laws, regulations, and requirements of other jurisdictions that may be applicable. ${ }^{162}$ The Bulletin also states that the "ERCB will continue to evaluate the process for regulating CCS operations in Alberta and will publish updates to that process as appropriate."163

A “clear regulatory framework" was among the key success factors recommended by the Alberta Carbon Capture and Storage Development Council as "essential to position Alberta as a world leader in CCS.” 164 Unfortunately, it does not appear that all aspects of a CCS project are covered by the existing regulatory regime. There appear to be no provisions, for example, for post-closure long-term monitoring, measurement, and verification of the sequestered $\mathrm{CO}_{2}$ after a certificate of closure has been issued to the lessee and liability has been assumed by the Crown. There is no mechanism for post-closure accountability. As well, a site-specific emergency response has not been required for $\mathrm{CO}_{2}$ pipelines.

While Bulletin 2010-22 provides that the "ERCB intends to use ... existing processes when processing applications for the development and operation of [CCS] projects"165 and refers specifically to ERCB Directive 071, many of the provisions of Directive 071 refer to sour gas. Although the terms “acid gas” and "sour gas” are often used interchangeably, a sour gas is a natural gas containing $\mathrm{H}_{2} \mathrm{~S} .{ }^{166} \mathrm{An}$ acid gas is gas that "is separated in the treating of solution or nonassociated gas that contains $\left[\mathrm{H}_{2} \mathrm{~S}\right]$, sulphide, totally reduced sulphur compounds, and/or $\mathrm{CO}_{2}$." ${ }^{167}$ Thus, $\mathrm{CO}_{2}$ by itself appears to be an acid gas but not a sour gas. While sections 3.2.3 and 3.2.5 of Directive 071, refer to acid gas pipelines and facilities, respectively, in discussing sour gas wells, section 3.2.1 makes no reference to acid gas. Apart from sections 3.2.3 and 3.2.5, there are no other references to acid gas in Directive 071 . While CCS project approval may or may not not entail (by analogy) application for sour gas well approval, the issue remains as to whether Directive 071 in its entirety potentially applies to CCS or whether only portions potentially apply.

Although the CS Tenure Regulation has addressed some of the items contemplated in the CCS Statutes Amendment Act, there remain a number of significant matters yet to be addressed by way of regulation. These include the duration of time which must pass before a closure certificate can be issued, the conditions that have to be met to obtain a closure certificate, what must be proven to establish that there is no significant risk of future leakage

$\begin{array}{ll}161 & \text { Ibid. } \\ 162 & \text { Ibid at } 1 . \\ 163 & \text { Ibid. } \\ 164 & \text { ACCSDC Interim Report, supra note } 67 \text { at } 6 . \\ 165 & \text { Bulletin 2010-22, supra note } 144 \text { at } 1 . \\ 166 & \text { Directive 071, supra note } 152 \text { at } 69 . \\ 167 & \text { Directive 056, supra note } 145 \text { at A-8. }\end{array}$


of the injected $\mathrm{CO}_{2}$, the type and amount of insurance that must be carried by the lessee and the amount of fees to be paid into the Post-closure Stewardship Fund. ${ }^{168}$

In order to address this, the Government of Alberta has recently initiated a Regulatory Framework Assessment to "ensure CCS projects are designed and operated in a safe and responsible way.... As part of this process, CCS experts from Alberta and around the world will examine in detail the technical, environmental, [geological, safety, assurance, measuring, monitoring and verification] requirements for CCS projects in Alberta” and determine what, if any, new processes need to be put in place for commercial scale deployment of this technology. ${ }^{169}$ "The assessment will be led by a multi-disciplinary steering committee that will be supported by an international panel of experts and several working groups." 170 The expert panel "will provide advice and peer review findings," the steering committee "will oversee the process and guide the scope of the review," and the working groups "will develop recommendations for the steering committee's consideration.” ${ }^{171}$ The Regulatory Framework Assessment will:

- $\quad$ review the current regulatory requirements in Alberta that apply to CCS;

- $\quad$ examine CCS frameworks from other jurisdictions; and

- $\quad$ identify opportunities for improvement in Alberta's regulatory framework. ${ }^{172}$

The Government of Alberta is hopeful that the review will result in the creation of a regulatory system that ensures CCS technology is "used safely in Alberta."173 The panel is to report to the Minister of Energy in the fall of 2012. ${ }^{174}$ It is anticipated that the review will result in a fully integrated legislative and policy framework for CCS projects in Alberta.

\section{Potential InTERJurisdictional Conflict}

Regulatory competence for CCS in Alberta is divided between the federal and provincial governments. Alberta has constitutional jurisdiction over natural resources within its boundaries, including the exploration and development of non-renewable natural resources and the management of electrical generation facilities. ${ }^{175}$ The federal government has

The Lieutenant Governor in Council may make regulations respecting insurance, as well as the "measurement, calculation or estimation of the quantity, quality or composition ... of captured carbon dioxide.” MMA, supra note 4, ss 5(1)(g.1), (1.2), as amended by CCS Statutes Amendment Act, supra note 1, ss 2(4)(b)-(c).

ADOE, Regulatory Framework Assessment (11 August 2011), online: ADOE < http://www.energy. alberta.ca/Initiatives/2840.asp > [RFA].

Ibid.

Government of Alberta, News Release, "International expertise to guide carbon capture and storage regulatory review" (11 March 2011), online: Government of Alberta <http://alberta.ca/acn/201103/ 30045A5A2059C-B0A9-5866-5BEC35F54255E39A.html > ["International expertise"]. The six-member expert panel will be co-chaired by Dr Stefan Bachu, Distinguished Scientist for $\mathrm{CO}_{2}$ Storage with Alberta Innovates - Technology Futures, and Don Thompson, President of the Oil Sands Developers Group. Other members include Lawrence E Bengal, Dr Andrew Chadwick, Dr Peter Cook and Dr Edward S Rubin. Dr Jeff Chapman and Barry Jones are part of the steering committee. RFA, supra note 169 .

Ibid.

"International expertise," supra note 171.

Constitution Act, 1867 (UK), 30 \& 31 Vict, c 3, reprinted in RSC 1985, App II, No 5, s 92A [Constitution Act]. 
constitutional jurisdiction over matters involving trade and commerce, international and interprovincial undertakings, taxation and criminal law. ${ }^{176}$ Alberta and the federal government share powers over environmental protection, ${ }^{177}$ including climate change mitigation measures. While CCS development and regulation for the most part fall within provincial jurisdiction, there are certain aspects of CCS over which the federal government has exclusive or shared jurisdiction.

Conflict may arise from the fact that Alberta has exclusive jurisdiction over the development of its natural resources, which is the main source of $\mathrm{CO}_{2}$ and other GHG. Federal actions intruding upon Alberta's exclusive jurisdictional powers may give rise to successful constitutional challenges. ${ }^{178}$ Apart from storage sites located upon federally owned lands, including First Nations reserves, or interfering with fisheries habitat or the habitat of migratory birds, the federal government's jurisdiction may be triggered where, for example, a provincial CCS storage domain crosses provincial or international boundaries. ${ }^{179}$ The same will be the case for any $\mathrm{CO}_{2}$ pipeline crossing provincial or international boundaries, ${ }^{180}$ which will then fall within the jurisdiction of the National Energy Board. ${ }^{181}$ Application for regulatory approval for CCS projects, particularly those involving large upstream emitters including oil sands projects, may trigger federal regulation under the Navigable Waters Protection Act, ${ }^{182}$ the Canadian Environmental Protection Act, $1999^{183}$ and the Fisheries Act ${ }^{184}$ which may in turn trigger application of the Canadian Environmental Assessment Act. ${ }^{185}$ The federal government also has the ability to regulate GHG emissions under the CEPA. $^{186}$

A further example of a potential federal/provincial jurisdictional conflict is in respect of the characterization of $\mathrm{CO}_{2}$. The federal government includes $\mathrm{CO}_{2}$ as a toxic substance under Schedule 1 of the CEPA. By contrast, the preamble to the Alberta Climate Change and Emissions Management Act, 2007 states that atmospheric carbon dioxide is "not toxic and [is] inextricably linked with the management of renewable and non-renewable natural

Ibid, ss 91(2)-(3), (27), 92(10)(a)-(c).

"The Federal Government can make laws to protect the environment based on a number of heads of power including the criminal law power ... and under the peace, order and good government power." Nigel Bankes, Legal Issues Associated with the Adoption of Commercial Scale CCS Projects (Drayton Valley, AB: Pembina Institute, 2008) at 28 [Bankes, "Pembina Institute"].

See Bachu, supra note 63 at 269. However, note that there have been instances of successful joint regulatory oversight of energy projects between the provincial and federal governments, for example, the oil sands, where some of the project activities trigger federal jurisdiction. This was possible due to the Canada-Alberta Agreement for Environmental Assessment Cooperation (2005), online: Canadian Environmental Assessment Agency <http://www.ceaa.gc.ca/default.asp?lang=En\&n=F93B8BF6-1>, which allows both levels of government to regulate without conflict and by minimizing administrative duplication.

Bachu, ibid at 261.

Ibid. In 1998 the National Energy Board approved the construction and operation of Canada's first international $\mathrm{CO}_{2}$ pipeline, the Souris Valley pipeline, which transports $\mathrm{CO}_{2}$ from the North Dakota Coal Gasification Plant to the Weyburn and Midale oil fields in Saskatchewan. See Reasons for Decision: Souris Valley Pipeline Limited, NEB Decision MH-1-98 (October 1998).

In the case of an intraprovincial pipeline, "[f]ederal jurisdiction will be much more limited ... although stream crossings may trigger some federal intervention and review." Bankes, "Pembina Institute," supra note 177 at 28 .

RSC 1985, c N-22.

SC 1999, с 33 [CEPA].

RSC 1985, c F-14.

Constitution Act, SC 1992, с 37.

CEPA, supra note 183 , s 160. 
resources.” ${ }^{\text {"187 }}$ The scope of federal jurisdiction over the capture and injection of $\mathrm{CO}_{2}$, in light of the characterization under the CEPA of $\mathrm{CO}_{2}$ as a "toxic substance," is uncertain.

It has been suggested that it is unlikely that the federal government will be able to rely upon its characterization of $\mathrm{CO}_{2}$ as a toxic substance in the CEPA as a lever to regulate CCS projects. ${ }^{188}$ In order to achieve regulatory oversight over CCS through the CEPA, the fundamental nature of CEPA would change, and instead of being federal "legislation in relation to criminal law it becomes regulatory and legislation in relation to property and civil rights, ${ }^{189}$ which are enumerated provincial heads of power. ${ }^{190}$ It would therefore be difficult to justify the use of federal powers under the CEPA to support such sweeping regulatory control.

There is commentary that characterizing $\mathrm{CO}_{2}$ as a waste, contaminant, or pollutant may expose "CCS operators to potential unlimited environmental liability" and may complicate the use of $\mathrm{CO}_{2}$ in EOR operations and in its transportability and storage from one jurisdiction to another. ${ }^{191}$ In this sense, there appears to be a conflict of objectives in Alberta's and Canada's characterization and regulation of $\mathrm{CO}_{2}$. Moreover, since the federal government sets its own emission targets and carbon pricing, differences in the allowable level and type of impurities in a $\mathrm{CO}_{2}$ stream may impact aspects regarding the transportation and storage of $\mathrm{CO}_{2}$, as well as eligibility for credits under various emissions reduction and trading regimes, since the trading of emission credits generated from CCS may extend beyond provincial boundaries. ${ }^{192}$

\section{COMPARISON OF AlbERTA's LEgISLATIVE CHANGES WITH OTHER CCS JURISDICTIONS}

In addition to Canada, CCS technology is being applied in a number of other countries including Norway, the United Kingdom, the United States, and Australia. This Part provides a preliminary comparison of Alberta's CCS legislative changes with the CCS regimes in the states of Queensland and Victoria in Australia, and the states of Wyoming and Montana in the US. These jurisdictions have been selected because they have legislation that specifically addresses onshore CCS projects. To further provide a comparative legal context for CCS, a brief review of the CCS framework in the European Union has also been included. The interjurisdictional comparison in this Part will focus only on the key issues of ownership and long-term liability.

191 Bachu, supra note 63 at 263, citing KA Coddington, “A Model CCS Code: Establishing the Regulatory Framework and Incentives to Enable Technology Deployment” (Paper delivered at the Fifth Annual 


\section{A. OWNERSHIP OF STORAgE Domain}

In Queensland, Australia, as in Alberta, the storage domain belongs to the state. Sections 27 and 28 of Queensland's Greenhouse Gas Storage Act $2009^{193}$ are very similar to Alberta's section 15.1 of the MMA. All onshore GHG storage reservoirs in Queensland are the property of the state, whether or not the land is freehold and regardless of who created or discovered the reservoir. ${ }^{194}$ Similar to Alberta's section 15.1 of the MMA, all GHG storage reservoirs are reservations in land grants, regardless of when the grant was made, reserving to the state the exclusive right to: (1) enter and carry out or authorize others to carry out any GHG storage activity; and (2) regulate GHG storage activities. ${ }^{195}$

Victoria's Greenhouse Gas Geological Sequestration Act $2008^{196}$ has taken a slightly different approach. In Victoria, although the Crown owns all underground geological storage formations below the land's surface despite any prior alienation, Crown ownership (except Crown lands) of underground geological storage formations is limited to formations deeper than 24 metres below the land's surface. ${ }^{197}$ This differs from Alberta, where the Crown owns all the pore space, but a minimum CCS injection depth of 1,000 metres has been set. As in Alberta and Queensland, the Crown in Victoria retains all rights to any underground geological storage formations in subsequent grants, unless expressly stated otherwise. ${ }^{198}$

Under Wyoming legislation, "pore space” is defined as "subsurface space which can be used as storage space for carbon dioxide or other substances."199 By contrast to Alberta, Queensland, and Victoria, the State of Wyoming declares ownership of all subsurface pore space to be vested in the owners of the surface immediately above the strata containing the pore space. ${ }^{200}$ As such, a conveyance of surface rights is a conveyance of the pore space in all strata below the surface of the real property conveyed, unless the ownership interest in such pore space has been expressly excluded in the conveyance or has been previously severed from the surface ownership. The conveyance of mineral or other subsurface interests does not convey ownership of any pore space in the strata unless the conveyance agreement expressly conveys that ownership interest. ${ }^{201}$

Unlike Alberta, it is clear in Wyoming that the rights belonging to, and the dominance of, the mineral estate have not been altered. With respect to the priority of subsurface uses between a severed mineral estate and pore space, the severed mineral estate has priority. ${ }^{202}$

Compared to Alberta, Montana legislation is not as clear in its determination of pore space ownership. The legislation states that it may not be construed to change or alter common law or other statutory provisions regarding the ownership of surface or subsurface rights. Further,

Ibid, s 27. For details of the operations see Greenhouse Gas Storage Regulation 2010, reprinted as in force 1 July 2011 (Qld).

GGSA, ibid, s 28.

Greenhouse Gas Geological Sequestration Act 2008 (Vic) [GGGSA].

Ibid, s 14.

Ibid, s 15.

Wyo Stat §34-1-152(d) (LEXIS through 2011 Sess) [WS 34-1].

Ibid, §34-1-152(a). See Session Laws of Wyoming, 2009 General Session, c 49-50.

WS 34-1, ibid, §34-1-152(b).

Ibid. 
"[i]f the ownership of the geologic storage reservoir cannot be determined from the deeds or severance documents related to the property [in accordance with the legislation] or common law, it is presumed that the surface owner owns the geologic storage reservoir." ${ }^{203}$ As well, the Montana legislation may not be construed to change or alter the common law as it relates to the "dominance of the mineral estate, including but not limited to the right to mine, drill, or recomplete a well, to inject substances, or to facilitate production, or to implement enhanced recovery for the purposes of recovery of oil, gas, or other minerals."204

\section{B. LONG-TERM LIABILITY}

One of the fundamental issues addressed by the CCS Statutes Amendment Act is the longterm liability for CCS projects. As discussed previously, as a result of the addition of new section 121 to the MMA, the provincial Crown will assume liability from the CCS operator when the Minister of Energy issues a closure certificate to a lessee. The only time the Crown will assume liability for the sequestered $\mathrm{CO}_{2}$ prior to the issuance of a closure certificate is when the lessee ceases to exist before the certificate is issued (such as CCS orphaned facilities).

In the US, the states of Wyoming and Montana have enacted legislation which specifically addresses long term CCS liability. The EU and Australia have also addressed liability by legislation specifically aimed at CCS projects. A brief synopsis of how these other jurisdictions have approached liability is set out below. ${ }^{205}$

\section{QUEENSLAND}

Unlike Alberta, a Queensland GHG lease does not have a fixed term and continues until it is surrendered or ends. ${ }^{206}$ After the decommissioning process is complete, as required under the GGSA, the state owns and becomes responsible for the GHG stream injected into a GHG storage reservoir and the associated wells. ${ }^{207}$ The lessee's application to surrender a GHG lease must be accompanied by a report setting out, among other things, "the applicant's suggestions for the approach to be taken by the State ... to monitor and verify the behaviour of the GHG streams." ${ }^{208}$ However, the Queensland GGSA does not expressly address longterm monitoring and liability obligations, or costs, the way Alberta's CCS Statutes Amendment Act does. The Queensland GGSA empowers the Minister to require a holder of, or applicant for, a GHG permit to provide the state with security which can be used to meet a range of costs specified in the GGSA. These include: (1) "any liability under [the GGSA] that the State incurs because of an act or omission of the [permit] holder"; (2) any unpaid amounts payable under the GGSA by the permit holder to the state such as unpaid civil liability; and (3) any debt payable in relation to the state's expenses in taking action to ensure 184.

204 MCA, ibid, §82-11-180(2)(a).

205 For an in-depth analysis see Allan Ingelson, Anne Kleffner \& Norma Nielson, "Long-Term Liability for Carbon Capture and Storage in Depleted North American Oil and Gas Reservoirs - A Comparative Analysis”(2010) 31:2 Energy LJ 431.

206 GGSA, supra note 193, s 134.

$207 \quad$ Ibid, ss 181, 269.

208 Ibid, s 177(f). 
permit holders undertake activities in compliance with their permit conditions. ${ }^{209}$ The security or part of the security given for a GHG authority may be kept for one year after the permit or approval has ended.

\section{VICTORIA}

In Victoria, the Crown becomes the owner of any GHG substance that has been injected into an underground geological formation, upon the cancellation or surrender of injection and monitoring. ${ }^{210}$ However, unlike in Queensland and Alberta, the GGGSA imposes a broad obligation on licence holders to meet the long-term monitoring and verification costs associated with CCS. This is a condition of the injection and monitoring licence separate from the requirements for insurance and rehabilitation bonds. The holder of the licence must pay an annual instalment of the estimated long-term monitoring and verification costs, as set out in the approved injection and monitoring plan. ${ }^{211}$ Upon surrender of the licence, the licence holder must pay any "remaining cost of carrying out long-term monitoring and verification as detailed in the long-term monitoring and verification plan."212 Unlike in Alberta where the Crown's liability includes an indemnity to CCS operators, the Victoria legislation does not contain a similar long-term indemnity (nor does the legislation of Queensland).

\section{WYOMING}

The State of Wyoming has approached the long-term liability issue on the assumption that potential participants will not be deterred from engaging in CCS projects as a result of their exposure to perpetual liability. In accordance with Wyoming legislation:

\footnotetext{
All carbon dioxide, and other substances injected incidental to the injection of carbon dioxide, injected into any geologic sequestration site for the purpose of geologic sequestration shall be presumed to be owned by the injector of such material and all rights, benefits, burdens and liabilities of such ownership shall belong to the injector. This presumption may be rebutted by a person claiming contrary ownership by a preponderance of the evidence in an action to establish ownership. ${ }^{213}$
}

In Wyoming, unlike in Alberta, liability related to $\mathrm{CO}_{2}$ sequestration rests indefinitely with the injector. There is no transfer of liability to the state. The Wyoming geologic sequestration special revenue account has been established, funded by project operators, to cover any monitoring, verification, and other costs incurred by the Department of Environmental Quality as a result of a default by the permit holder. Public liability insurance, bonding, and financial assurance requirements have also been established to insulate the state against project participant default.

The owner of pore space, other persons holding any right to control pore space, or other surface or subsurface interest holders, shall not be liable for the effects of injecting $\mathrm{CO}_{2}$ or

\footnotetext{
209 Ibid, s 270.

210 GGGSA, supra note 196, s 16.

$211 \quad$ Ibid, s 112.

212 Ibid, s 174.

213 WS 34-1, supra note 199, §34-1-153(a) [emphasis added].
} 
other incidental substances for sequestration purposes, "solely by virtue of their interest or by their having given consent to the injection."214

\section{MONTANA}

Montana has employed a variation of the Australian, Alberta, and Wyoming models. Although ownership of pore space may belong to the surface owner, long-term liability of the sequestered $\mathrm{CO}_{2}$ is transferred to the state. After $\mathrm{CO}_{2}$ injection ends, and upon completion of the certification requirements under the Act, the Board of Oil and Gas Conservation (the Montana Board) is required to issue to the operator a certificate of project completion. ${ }^{215}$ However, "[t]he certificate may not be issued until at least 15 years after carbon dioxide injections end." 216

The Montana Board is required to adopt rules necessary for implementing certification requirements, including rules for public notice and hearing, and must solicit, record, consider, and address comments from the Montana Department of Environmental Quality prior to issuing a certificate of completion. ${ }^{217}$ "After issuing a certificate of completion, the [Montana Board] shall ensure adequate monitoring by the operator of the wells and reservoir" for a further period of 15 years. ${ }^{218}$ If the operator has title to the storage reservoir and the stored $\mathrm{CO}_{2}$, the operator may transfer to the State of Montana title to the storage reservoir and to the stored $\mathrm{CO}_{2}$ following the 15 -year monitoring and verification period (that is, 30 years in total since the $\mathrm{CO}_{2}$ injection has ceased). The ability to transfer can occur provided "the reservoir and wells are in full compliance with the regulations" and "the reservoir will maintain its structural integrity and will not allow carbon dioxide to move out of one stratum into another or pollute drinking water supplies.”219

The Montana Board is required to make a recommendation to the Montana Board of Land Commissioners as to whether title should transfer to the state. The Montana Board of Land Commissioners must make the final decision on the transfer of title. ${ }^{220}$ Where liability is transferred to the state, title is transferred without payment or any compensation, and the state acquires

all rights and interests in and all responsibilities associated with the geologic storage reservoir and the stored carbon dioxide.... [The] operator and all persons who generated any injected carbon dioxide are released from all regulatory requirements and liability associated with the ... storage reservoir and the stored carbon dioxide.... [Any] bonds or other surety posted by the ... operator must be released; and ... monitoring and managing the ... storage reservoir and the stored carbon dioxide [becomes] the state's responsibility to be overseen by the [Montana Board] until the federal government assumes responsibility for the long-term monitoring and management. ${ }^{221}$

Ibid, §34-1-153(b).

MCA, supra note 203, §82-11-183(1).

Ibid, §82-11-183(3).

Ibid, §§82-11-183(2), 82-11-183(5)(a).

Ibid, §82-11-183(6).

Ibid, §82-11-183(7)(b).

Ibid, §82-11-183(7)(c).

Ibid, §82-11-183(8). 
There are two instances where an operator may retain liability after the 30 -year period has elapsed since $\mathrm{CO}_{2}$ injections have ceased. The first is where the operator chooses to not transfer title to the state, in which case the operator "indefinitely accepts liability" until it chooses to petition the Montana Board for a transfer. ${ }^{222}$ The second instance is where the operator's monitoring does not establish that the reservoir will maintain its structural integrity or is not in full compliance with the regulations, in which case the operator will retain liability until it is able to meet the regulatory requirements. ${ }^{223}$ For operators who were eligible, but did not transfer title to the state, the operator may petition the Montana Board every 15 years after completing the monitoring and verification required, and request that liability be transferred to the state and that it be released from liability. ${ }^{224}$ Until the certificate of project completion is issued and title to the stored $\mathrm{CO}_{2}$ and storage reservoir is transferred to the state, the operator remains liable for the operation and management of the carbon dioxide injection well, the geologic storage reservoir, and the injected or stored carbon dioxide. ${ }^{225}$ A bond or other surety is required and must be adequate to meet the operator's liabilities. $^{226}$

Like Alberta, the Montana legislation creates a fund and requires operators to pay administrative fees. In Montana, an operator is required to pay to the Montana Board a fee based on each tonne of $\mathrm{CO}_{2}$ injected for storage, to be used by the state in carrying out its responsibility to monitor and manage the storage reservoirs. ${ }^{227}$ "The amount must be based on the anticipated actual expenses that the [Montana Board] will incur in monitoring and managing the ... storage reservoirs during their postclosure phases.”228 If an operator chooses to retain liability indefinitely, the Montana Board must return the administrative fee to the operator. However, if an operator is required to maintain liability due to non-compliance with the regulations, the Montana Board may not return the fee. ${ }^{229}$ A geologic storage reservoir program account is created in a special revenue fund. ${ }^{230}$ The administrative fees collected by the Montana Board and funds received from bonds or other surety must be deposited in the account each fiscal year. ${ }^{231}$

\section{EUROPEAN UNION}

In 2008 the EU enacted legislation providing for the same conditional transfer of longterm liability as enacted by the State of Montana. The legislation in the EU, however, is much more comprehensive. ${ }^{232}$

The European Commission released a "Climate and Energy" package that included a proposal for a Directive on $\mathrm{CO}_{2}$ storage for $\mathrm{CO}_{2}$ projects. ${ }^{233}$ It set out a framework for a

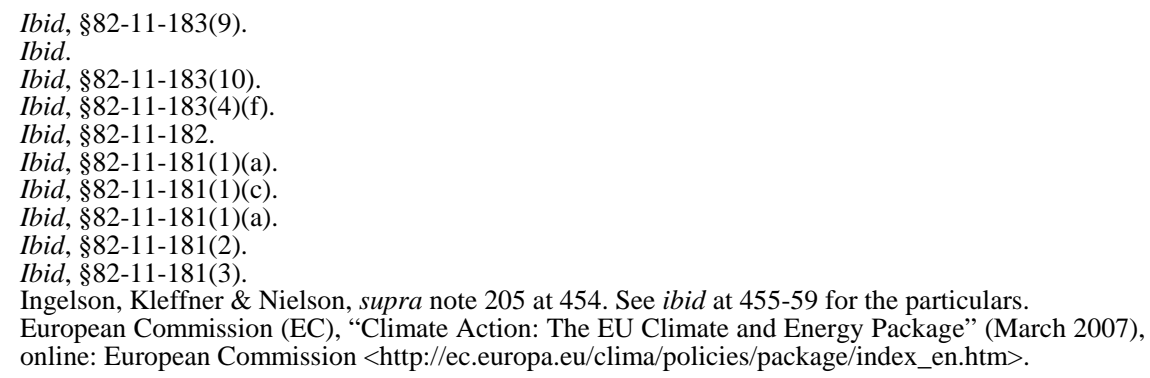


number of items, including the ultimate transfer of long-term liability to the state. In accordance with Directive 2009/31/EC, in force 25 June 2009, Member States must bring into force their laws, regulations, and administrative provisions to comply with the Directive by 25 June $2011 .{ }^{234}$ Provisions are required by Member States addressing liability for damage to the environment and climate arising as a result of the failed containment of the sequestered $\mathrm{CO}_{2}{ }^{235}$

$\mathrm{A} \mathrm{CO}_{2}$ storage site may be closed if the conditions in the permit have been satisfied and if the competent authority authorizes the closure. Unlike Alberta, after closure, the operator will remain responsible for, among other things, the maintenance, monitoring, and control of the site, and for corrective measures and all ensuing obligations until the responsibility for the site has been transferred to the competent authority. ${ }^{236}$ A transfer of responsibility may occur if, among other things, all "available evidence indicates that the stored $\mathrm{CO}_{2}$ will be completely and permanently contained.”237 Prior to a transfer of responsibility, the operator must make a financial contribution available to the competent authority, which will be in an amount to cover at least the anticipated cost of monitoring for a period of 30 years. ${ }^{238}$ Following the transfer of responsibility, the competent authority is unable to recover any costs incurred by it except in the case of fault on the part of an operator before the transfer of responsibility occurred. ${ }^{239}$

\section{CONCLUSIONS}

The development of CCS projects is a cornerstone of Canada's emissions reduction strategy generally, and in meeting emissions targets in particular. The policy history, both in Alberta and federally, has led to the development of the CCS Statutes Amendment Act. That history involved an emphasis on developing viable climate change frameworks and CCS project financing. Regulation of the CCS projects themselves, the nature of which remains to unfold in a post-CCS Statutes Amendment Act environment, developed apart from CCS policy and was driven largely by the ERCB in its consideration of analogous technologies, including AGD and EOR schemes.

The CCS Statutes Amendment Act is landmark legislation. Alberta is not only the first jurisdiction in Canada to enact comprehensive CCS legislation, but also, within the context of CCS, the first to address pore space ownership and long-term liability for injected $\mathrm{CO}_{2}$. With respect to ownership issues, the CCS Statutes Amendment Act makes clear that the pore space below the surface of all non-federal Crown land in Alberta is the property of the Crown in right of Alberta. The legislation is also clear on liability, specifically mandating that the Province of Alberta will accept long-term liability for injected $\mathrm{CO}_{2}$.

Directives EC, Directive 2009/31/EC of the European Parliament and of the Council of 23 April 2009 on the geological storage of carbon dioxide and amending Council Directive 85/337/EEC, European Parliament and Council Directives 2000/60/EC, 2001/80/EC, 2004/34/EC, 2006/12/EC,2008/1/EC and Regulation (EC) No 1013, 2006, [2009] OJ, L 140/114 at art 39(1) [Directive 2009/31/EC].

Ibid at Preamble (30).

Ibid at Preamble (32).

Ingelson, Kleffner \& Nielson, supra note 205 at 458.

Directive 2009/31/EC, supra note 234 at Preamble (37).

Ibid, art 17(7). 
Notwithstanding the passage of the CCS Statutes Amendment Act and CS Tenure Regulation, uncertainties remain surrounding regulatory treatment of CCS projects. Much of the regulatory framework for CCS projects is anticipated to evolve. A further uncertainty is that regulatory oversight of CCS is divided between the provincial and federal governments and, therefore, subject to federal/provincial jurisdictional conflicts over issues which include the characterization of $\mathrm{CO}_{2}$ as toxic substance. However, when compared to the CCS regimes in other jurisdictions, Alberta's legislative changes appear to be more certain, have lower compliance costs, and be more attractive to CCS investors. 